\title{
PENNSTATE
}

Qne

$8 \begin{array}{lll}8 & 5 & 5\end{array}$

Annual Progress Report

For the Period

May 2001 - June 2002

On

\section{Impact of DME-Diesel Fuel Blend Properties on Diesel Fuel Injection Systems}

by

Elana M. Chapman and André L. Boehman

The Energy Institute

Kimberly Wain, Wallis Lloyd and Joseph M. Perez

Department of Chemical Engineering

Donald Stiver

Applied Research Laboratory

and

Joseph Conway

Department of Engineering Science and Mechanics

Work Performed for

National Energy Technology Laboratory

Pittsburgh, PA

Under

Contract No. DE-FC26-01NT41115

Work Performed by

The Energy Institute

Departments of Chemical Engineering and Engineering Science and Mechanics

The Applied Research Laboratory

The Pennsylvania State University

University Park, PA 16802

July, 2002 


\section{TABLE OF CONTENTS}

Table of Contents ……........................................................................................... ii

Executive Summary ......................................................................................... iii

Introduction ………....................................................................................... 1

TASK 1. Wear Rate and Lubricity Measurements of DME-Diesel Fuel Blends 3

TASK 2. Injector Durability Studies …………………………………………..... 8

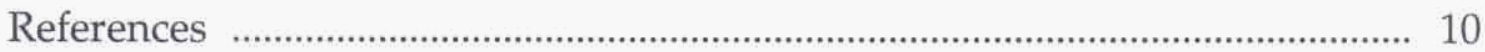

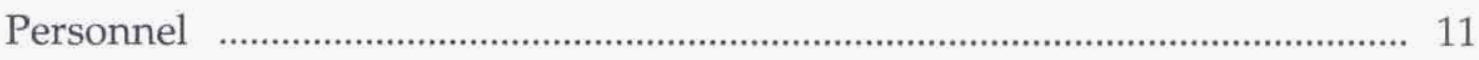

Acknowledgement ………………............................................................... 12 


\section{EXECUTIVE SUMMARY}

The objectives of this research program are to develop information on lubricity and viscosity improvers and their impact on the wear mechanisms in fuel injectors operating on blends of dimethyl ether (DME) and diesel fuel. This project complements another ongoing project titled "Development of a Dimethyl Ether (DME)-Fueled Shuttle Bus Demonstration Project," under agreement \#DE-FG29-99FT40161. The objectives of that research and demonstration program are to convert a campus shuttle bus to operation on dimethyl ether, a potential ultra-clean alternative diesel fuel. To accomplish this objective, this project includes laboratory evaluation of a fuel conversion strategy, as well as, field demonstration of the DME-fueled shuttle bus. Since DME is a fuel with no lubricity (i.e., it does not possess the lubricating quality of diesel fuel), conventional fuel delivery and fuel injection systems are not compatible with dimethyl ether. Therefore, to operate a diesel engine on DME one must develop a fuel-tolerant injection system, or find a way to provide the necessary lubricity to the DME. In the shuttle bus project, we have chosen the latter strategy in order to achieve the objective with minimal need to modify the engine. Our strategy is to blend DME with diesel fuel, to obtain the necessary lubricity to protect the fuel injection system and to achieve low emissions. In this project, we have sought to develop methods for extending the permissible DME content in the DME-diesel blends without experiencing rapid injector failure due to wear.

To date, our activities have covered two areas: development of a high-pressure lubricity test apparatus for studies of lubricity and viscosity improvers and development of an injector durability stand for evaluation of wear rates in fuel injectors.

The lubricity apparatus is being constructed by adding a high pressure cell to an existing Cameron-Plint reciprocating wear machine. The high pressure cell permits the flooding of the chamber with blends of DME with other fuels and additives and the reciprocating wear of a test specimen (pin) against another surface (cylinder). The pin is provided by Caterpillar and is the pin used in the fabrication of the Hydraulic Electronic Unit Injectors (HEUI) that are used in the Navistar V-8 turbodiesel engine that is used in the DME Shuttle Bus project, and which are the focus of both of these studies.

The injector durability stand was originally going to be fabricated at Penn State with input from Navistar and Caterpillar, both of which have provided support for the DME research at Penn State. However, the cost and complexity of building such a system, and the potential of receiving a donation of an existing instrument led to a change in this part of the project plan. Earlier this year, Caterpillar expressed confidence that a HEUI Endurance Stand could be donated for the project. However, this week Caterpillar informed us that their management has turned down the request for donation. At present, we are pursuing other avenues within Caterpillar to gain approval for the donation. The stand is the industry standard apparatus for examining the time-to-failure of HEUI fuel injectors.

This report provides summaries of the progress toward completion of both experimental systems and a summary of the plan for completion of the project objectives. 


\section{INTRODUCTION}

This project is driven by the desire to utilize dimethyl ether as an ultra-clean transportation fuels. Dimethyl ether (DME) can be a replacement diesel fuel that lowers emissions significantly, if it's low lubricity and low viscosity can be overcome. There are two methods for utilizing DME: design injection systems that can tolerate the low lubricity and low viscosity of DME; or develop fuel formulations (through blending or additives) that give physical properties to DME mixtures that fall within conventional diesel fuel ranges. Following the latter approach, we have been examining the co-firing of the engine on diesel fuel and dimethyl ether, using the diesel fuel as a lubricating agent to protect the fuel pump and fuel injection system from excessive wear. Dimethyl ether has no natural lubricity, making it antagonistic to fuel system components.

The interest in operating diesel engines on DME arose initially from a collaboration between Penn State and Air Products and Chemicals to develop a campus shuttle bus that could operate on DME. That project, which is also supported by the Pennsylvania Department of Environmental Protection and the National Energy Technology Laboratory (agreement \# DEFG29-99FT40161), has focused on blending DME with sufficient diesel fuel to provide an acceptable mixture viscosity and lubricity to be compatible with existing diesel engine technology.

Due to the low viscosity of DME (on the order of $0.2 \mathrm{cSt}$ at $40^{\circ} \mathrm{C}[1,2]$ ), the blend ratio that the shuttle bus project is limited to is $25 \mathrm{wt} . \%$, a finding that has come out of the other NETLsponsored project. Figure 1 shows the blend response of the mixture viscosity to variations in DME content.

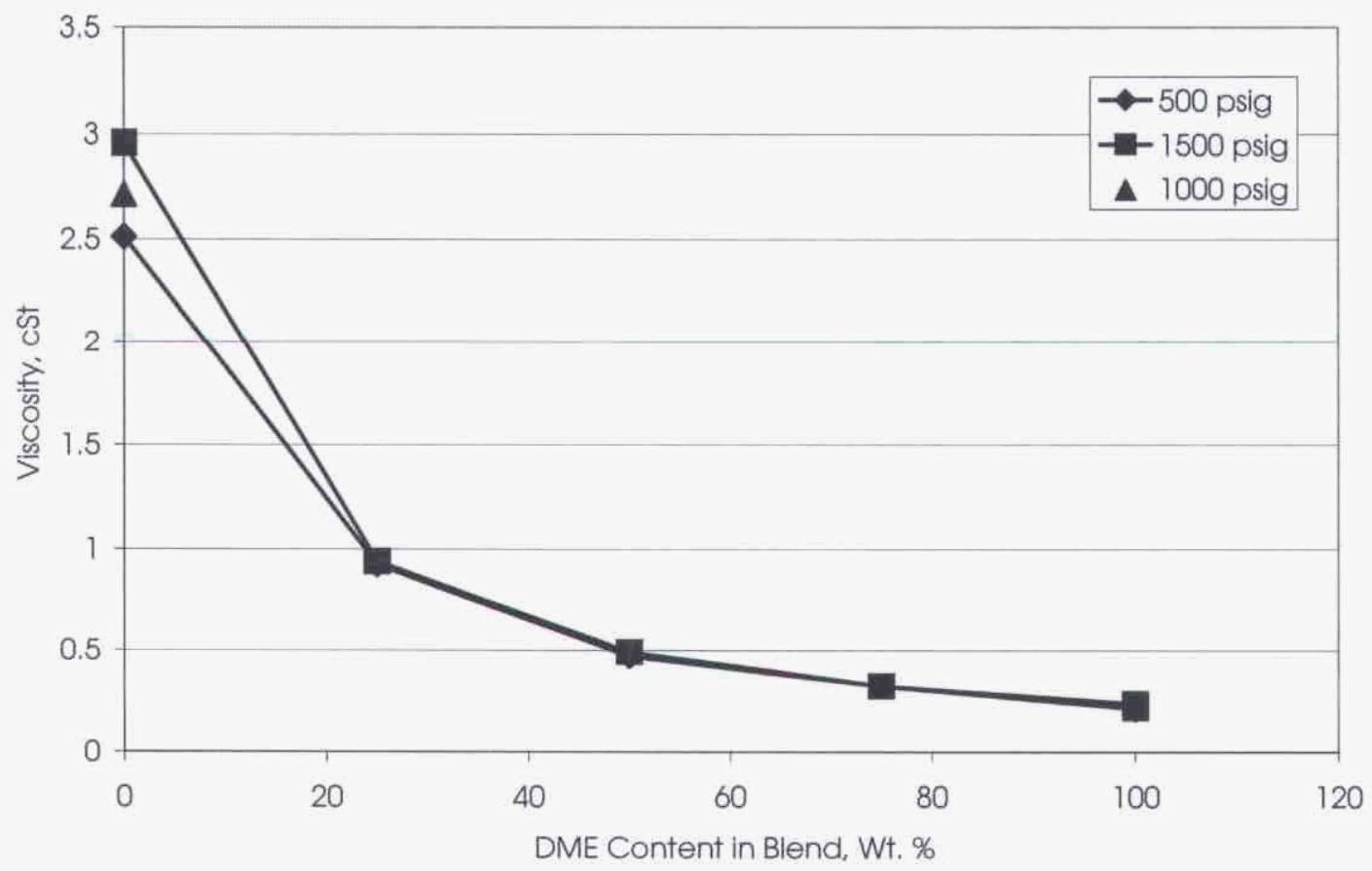

Figure 1. Viscosity - DME Content Relationship at Different Pressures@100 F 
As Figure 1 shows, at $25 \mathrm{wt}$ \% DME the viscosity drops to roughly $1 \mathrm{cSt}$ which is the lower limit of the ASTM specification for diesel fuel viscosity. To increase the allowable DME without exposing the injectors to excessive wear and early failure, both the lubricity and the viscosity of the fuel blend must be kept within the ASTM specifications. To that end and to raise the allowable DME content in the mixture, the present work focuses in parallel on selection and development of additives to improve lubricity and viscosity of DME fuel blends.

In our laboratory engine, we have demonstrated effective operation on the 25 wt.\% DME blended fuel. Through collaboration with the Tribology Laboratory in Penn State's Chemical Engineering Department, we are characterizing the viscosity, compressibility and miscibility of blends of DME, diesel fuel and the additives under pressures and temperatures relevant to the fuel injection system. These tests are using a high pressure viscometer adapted to these specific experiments. This instrument, combined with a high pressure cell for lubricity studies and an injector durability stand to demonstrate injector time-to-failure, provides us with the ability to determine if additives can be used to increase DME content in the blended fuel while not sacrificing injector lifetime.

At present, we are in the process of modifying an existing Cameron-Plint reciprocating wear test apparatus to investigate the lubricity of DME blends with diesel fuel and lubricity and viscosity improvers. We are also working to acquire an injector durability stand from industry to assist in injector wear characterization.

Caterpillar (manufacturer of the HEUI fuel injectors on the Navistar T444E turbodiesel engine) has agreed to participate in this project on injector durability and they have already provided 6 sets of HEUI injectors ( 8 injectors per set, total retail value of over $\$ 24,000$ ) for this project. One set has been installed in the DME Shuttle Bus to provide some field data on wear rates using DME diesel blends. The rest will be used in the injector durability stand. Caterpillar is also considering donation of a HEUI Endurance Stand for the injector durability studies.

The rest of this report consists of a section for each of the major activities (tasks) under the project.

- Task 1. Wear Rate and Lubricity Measurements of DME-Diesel Fuel Blends

- Task 2. Injector Durability Studies 


\section{TASK 1. WEAR RATE AND LUBRICITY MEASUREMENTS OF DME-DIESEL FUEL BLENDS}

In this task, we are converting an existing instrument to studies of lubricity of fuels and additives so as to screen lubricity and viscosity improvers for DME fuel blends. The additives that show promise with then be tested in the fuel injector durability tests (Task 2) and subsequently could be tested in the laboratory engine or field vehicle. The major of the work in this first year of the project focused on design of a high pressure cell to permit reciprocating wear tests that are relevant to the operation of the HEUI fuel injectors and that permit examination of additives in DME fuel blends. Thus, the modified apparatus needs to be able to operate at a nominal pressure of 150 psig and the cause wear of components similar in composition and design to those within the HEUI injector.

The apparatus selected for this project is a Cameron-Plint reciprocating wear test apparatus that permits tightly controlled operation of a reciprocating element and measurement of load and speed of movement. The additional components for the Cameron-Plint are a cell that connects to the reciprocating mechanism and internally, a component that reciprocates and wears against another material. To simulate the interactions within the HEUI injector the pin

\section{HEUI INJECTOR}
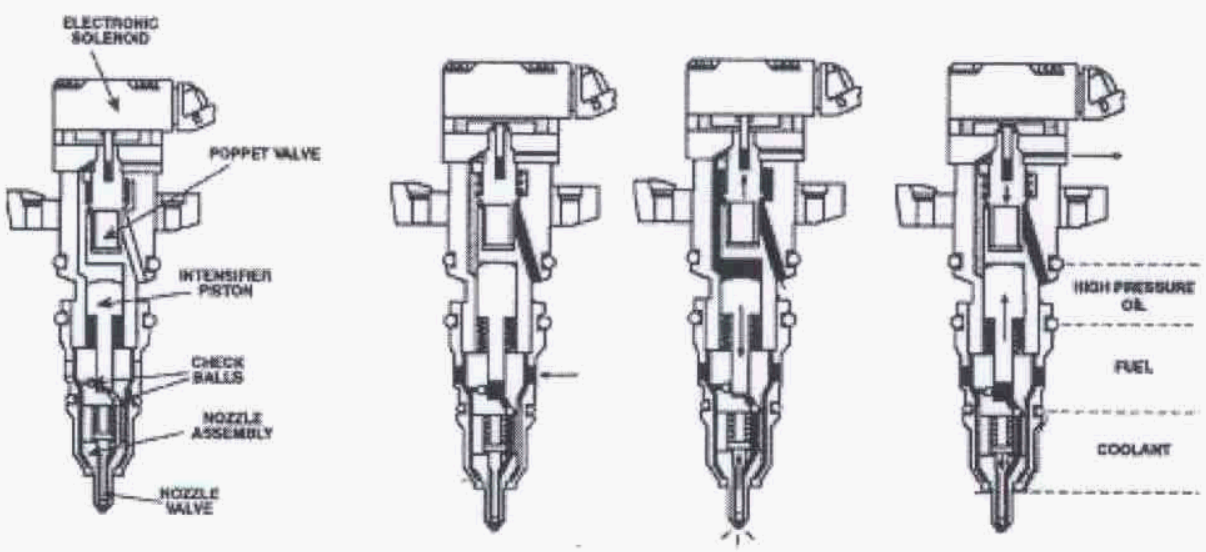

1. FILL CYCLE

2. INJECTION

3. END OF INJECTION

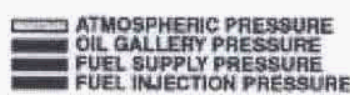

$E G-1258$

Figure 2. Schematic Diagram of the HEUI ${ }^{\mathrm{TM}}$ Injector

The wear component that will experience the reciprocating motion and will wear within the high pressure cell is the pin that serves as the Nozzle Valve seen in Figure 2. These pins have been acquired from Caterpillar and will be mounted within the lubricity test cell. The pin will slide within a cylinder (or barrel) with a very tight tolerance. The wear mechanisms is likely a direct 
sliding wear between the pin and the cylinder (i.e., a scuffing wear) that is affected by the lubricating quality of the surrounding fluid (hydrodynamic lubrication) and the viscosity of the surrounding fluid (boundary layer lubrication).

The cell design is outlined in the following sequence of sketches. The fabrication of the cell has been completed and the instrument should be operational by September 2002 .

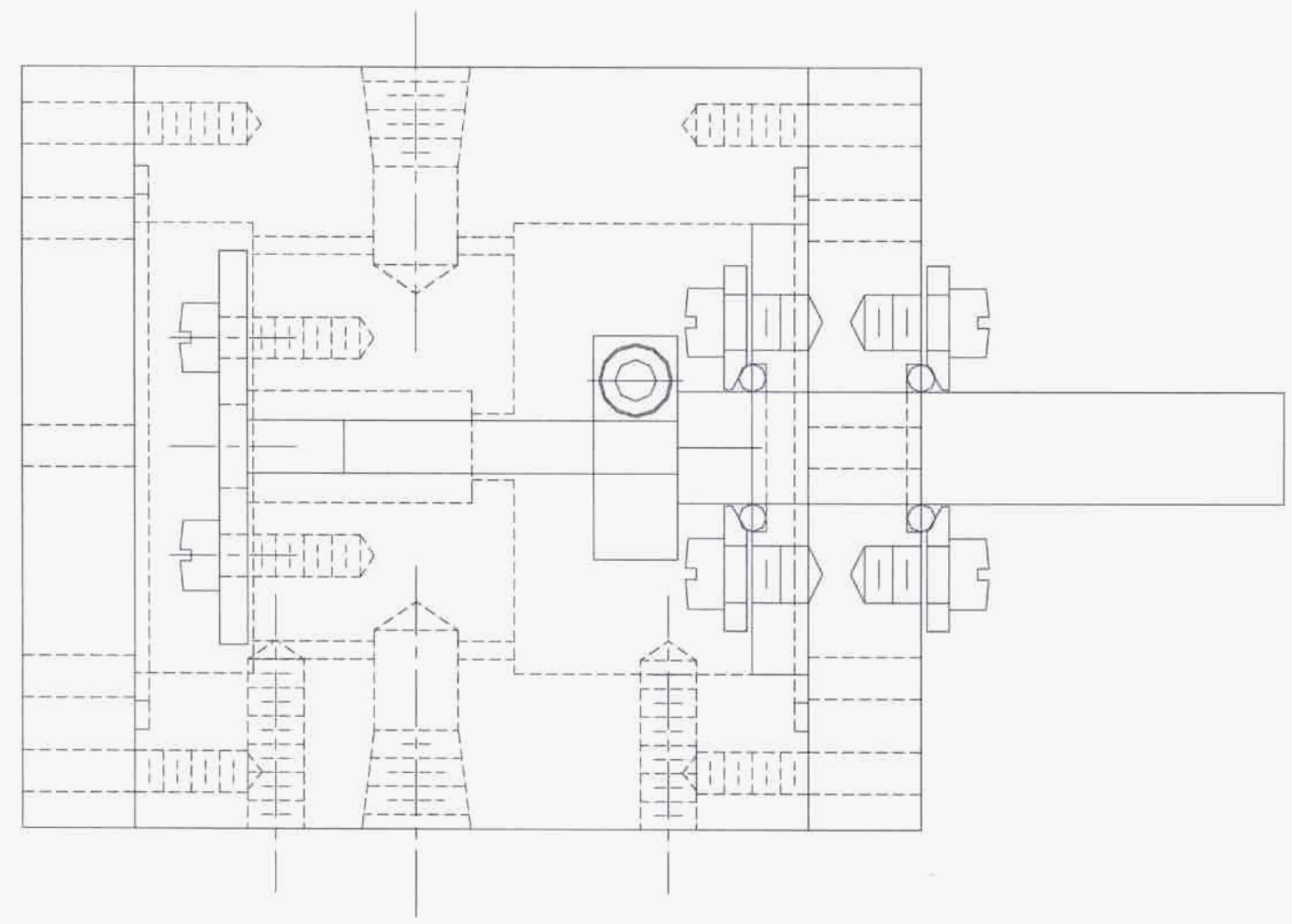

Figure 3. Overall view of DME wear test cell 


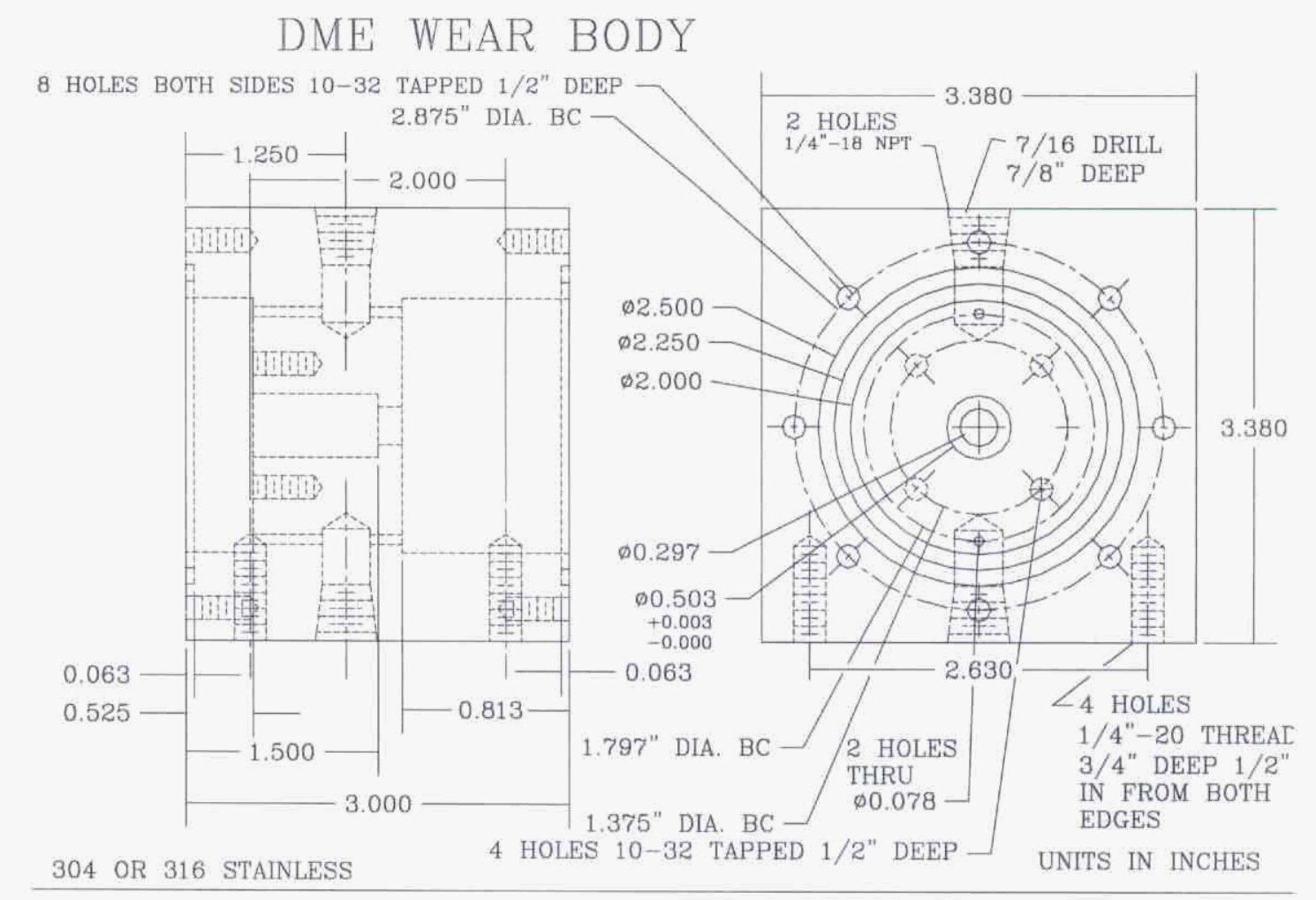

Figure 4. Technical drawing of the main cell for the DME wear test apparatus

8 HOLES $3 / 16$ " THRU ON 2.875" BC 7 END PLATE
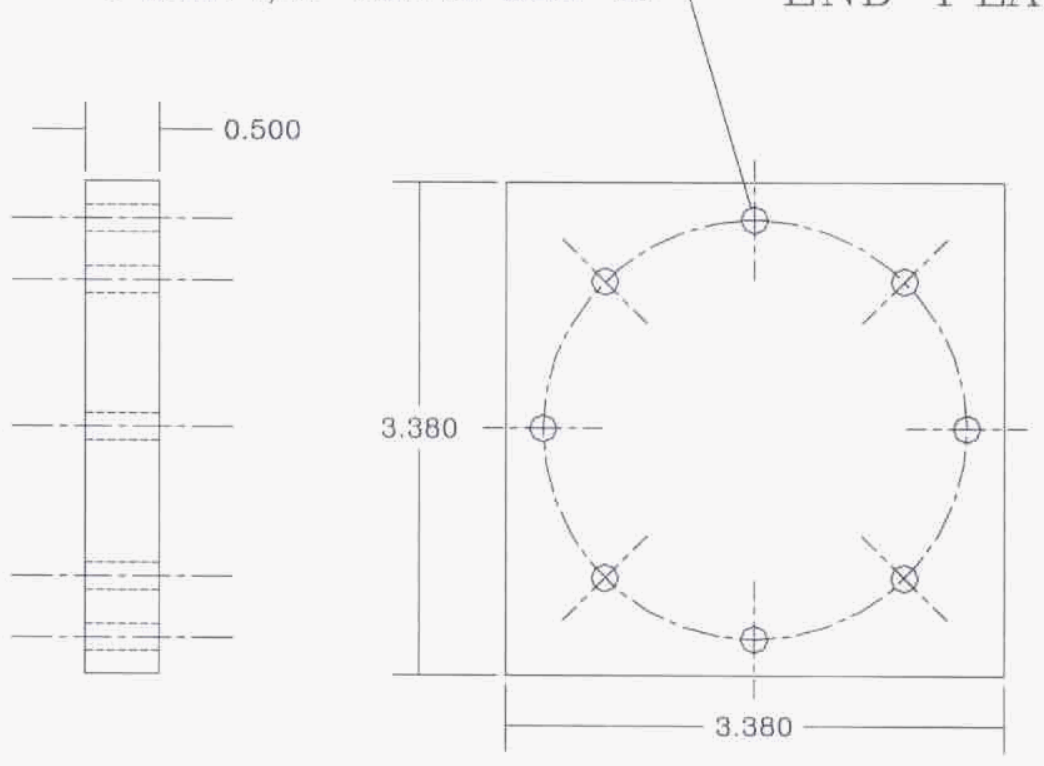

MATERIAL: 304 OR 316 SS

UNITS IN INCHES

Figure 5. End plate for wear test cell 
PISTON END PLATE

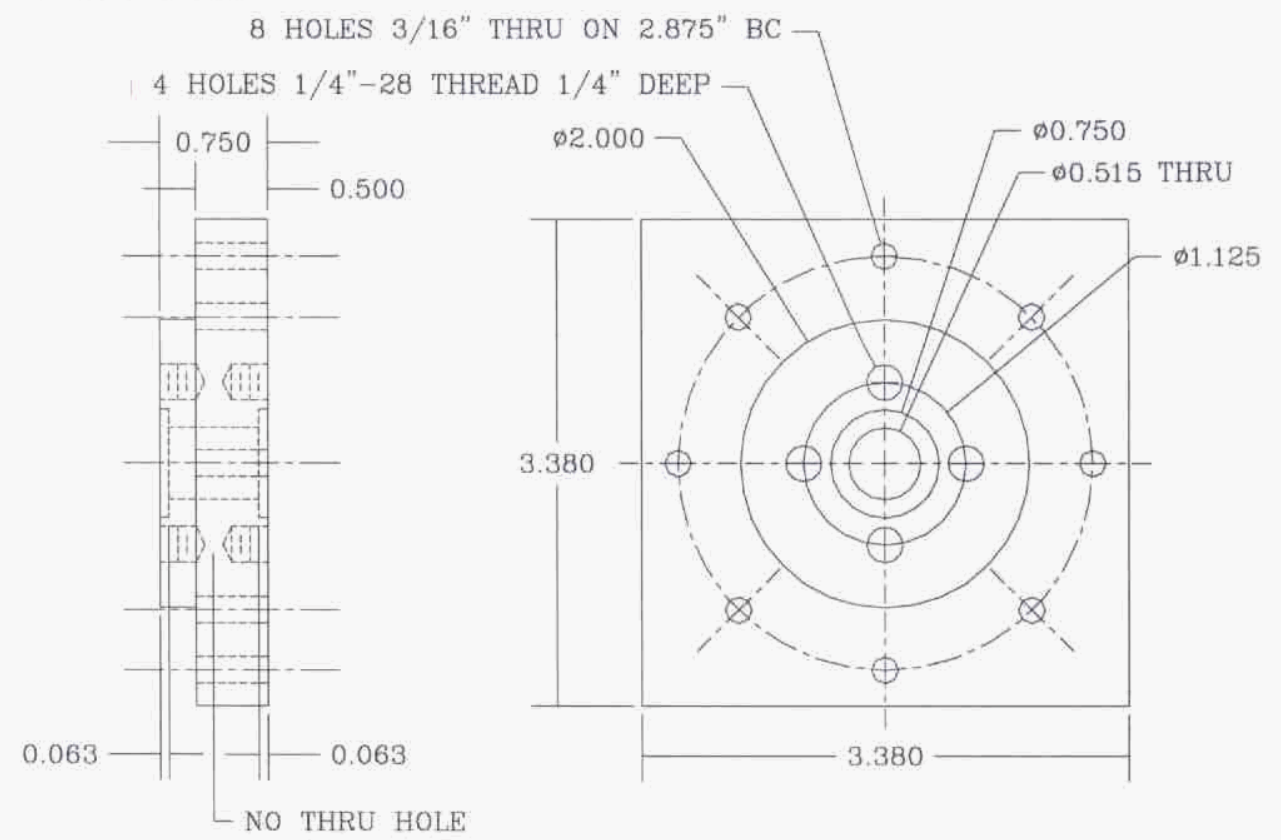

MATERIAL: 304 OR 316 SS

UNITS IN INCHES

Figure 6. Piston end plate through which reciprocating motion is transferred

\section{CYLINDER SPECIMEN}

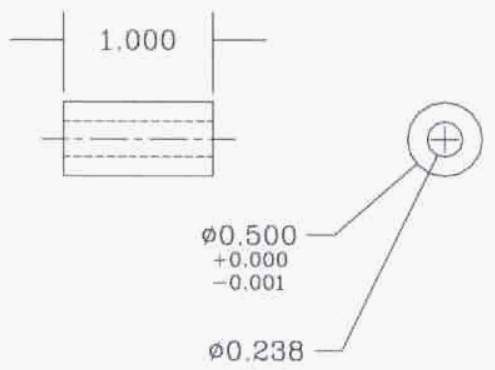

MATERIAL:

UNITS IN INCHES

Figure 7. Cylinder in which the injector "pin" will travel 


\section{DME PIN SPECIMEN}
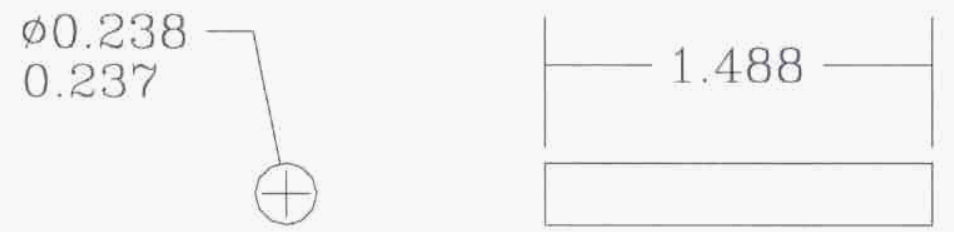

Figure 8. Pin from HEUI injector that will travel within the cylinder and wear against the cylinder while surrounded by the test fluid 


\section{TASK 2. INJECTOR DURABILITY STUDIES}

Once lubricity and viscosity improvers have been selected or developed, they need to be tested in actual injectors to assess their ability to delay failure of the injectors through wear. To accomplish the operation of HEUI fuel injectors on test fuel blends and additives, a system is needed to support, operate and deliver fuel mixtures to the injector. At Caterpillar such systems are referred to as Endurance Stands. This injector durability stand was originally going to be fabricated at Penn State with input from Navistar and Caterpillar, both of which have provided support for the DME research at Penn State. However, the cost and complexity of building such a system led to a change in this part of the project plan. Instead of developing an in-house system at Penn State, we began discussions with Michigan Custom Machines (MCM) Inc. who previously built HEUI injector stands for Caterpillar. MCM estimated that a complete stand would cost a minimum of $\$ 125,000$, but that a simpler stand that had been built for a customer and not delivered could be provided for $\$ 30,000$. Neither of these prices was compatible with the budget for this project, so a third option was investigated, that of obtaining a donation of a system for use at Penn State.

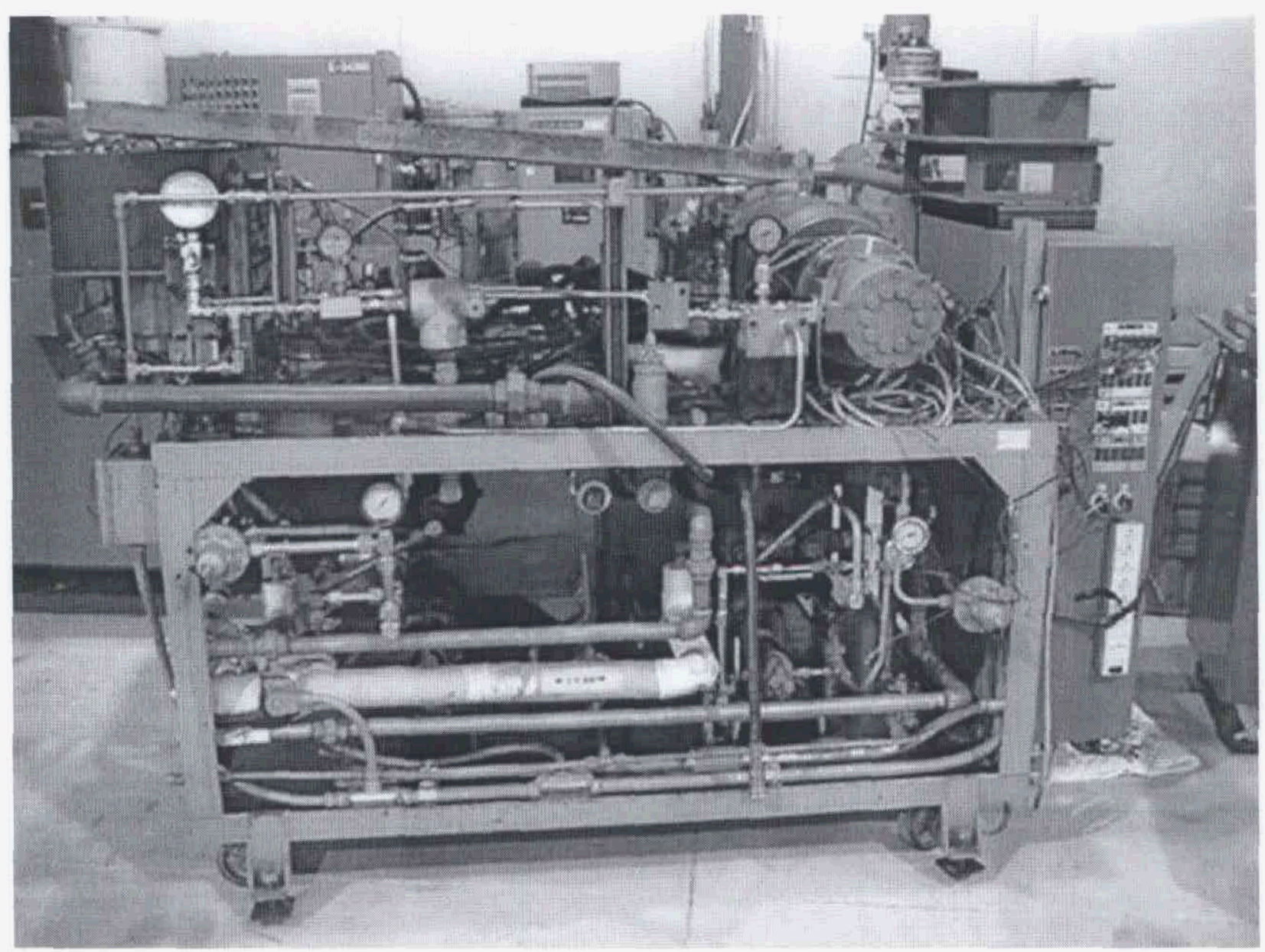

Figure 9. HEUI Endurance Stand for injector durability studies 
So, we approached Caterpillar with a request for a donation of additional equipment, specifically a HEUI Endurance Stand which is shown in Figure 9 (this would be in addition to their existing commitment to supply fuel injectors and technical services to this project). In response, Caterpillar informed us early this year that a HEUI Endurance Stand could be donated to Penn State, pending approval by upper management. However, this week Caterpillar informed us that their management has turned down the request for donation due to changes in the financial picture for their fuel systems unit. At present, we are pursuing other avenues within Caterpillar to gain approval for the donation. The stand is the industry standard apparatus for examining the time-to-failure of HEUI fuel injectors, and would provide essential experimental capabilities for gauging the performance of viscosity and lubricity enhancing additives.

If we cannot work out an arrangement with Caterpillar to receive a donation of the Endurance Stand, they have offered to test some fuels for us at their facilities. Another option would be to use our instrumented Navistar T444E turbodiesel engine as a means of running injectors to failure. The difficulty with this approach will be that we cannot accelerate the number of cycles experienced by the injector, so only the most aggressive fuel formulations (e.g., neat DME or nearly neat DME) would provide failure information in a reasonable test period. Also, the fuel requirements to operate the engine for long periods of time would be significant. 


\section{REFERENCES}

[1] Bhide, S.V., Boehman, A.L. and Perez, J.M., "Viscosity of DME-Diesel Fuel Blends," in ACS Fuel Chemistry Division Preprints, 46(2), 400-401 (2001).

[2] Sivebaek, I. M., Sorenson, S. C., and Jakobsen, J., 2001, SAE paper no. 2001-01-2013. 


\section{PERSONNEL}

The following personnel are involved in this project. Briefly listed below are their affiliations and current duties.

André L. Boehman, Ph.D., P.E.

Associate Professor of Fuel Science

Department of Energy and Geo-Environmental Engineering

Duties: Principal Investigator

Joseph Conway, Ph.D.

Professor of Engineering Mechanics

Department of Engineering Science and Mechanics

Duties: Co-Investigator

Joseph Perez, Ph.D.

Adjunct Professor

Department of Chemical Engineering

Duties: Co-Investigator

Wallis Lloyd, Ph.D.

Department of Chemical Engineering

Duties: Experiment Design and Supervision of Graduate Students

\section{Elana Chapman}

Graduate Assistant

The Energy Institute at Penn State

Duties: Experiment design and operation

\section{Kimberly Wain}

Graduate Assistant

Department of Chemical Engineering

Duties: Experiment design and operation

\section{Don Stiver}

Assistant Research Engineer

Applied Research Laboratory

Duties: Experiment design and fabrication 


\section{ACKNOWLEDGMENT}

We are grateful to the National Energy Technology Laboratory for supporting this work. We would also like to thank Ron Wennmacher and Karl Sickman of Caterpillar for their support and assistance. 